European journal of American studies

Summer 2015, including Special Issue: (Re)visioning America in the Graphic Novel

\title{
Body Matters: Mina Loy and the Art of Intuition
}

\section{Ellen McWhorter}

\section{(2) OpenEdition \\ Journals}

Electronic version

URL: https://journals.openedition.org/ejas/11056

DOI: $10.4000 /$ ejas. 11056

ISSN: 1991-9336

Publisher

European Association for American Studies

\section{Electronic reference}

Ellen McWhorter, "Body Matters: Mina Loy and the Art of Intuition", European journal of American studies [Online], 10-2 | 2015, document 12, Online since 14 August 2015, connection on 08 July 2021. URL:

http://journals.openedition.org/ejas/11056 ; DOl: https://doi.org/10.4000/ejas.11056

This text was automatically generated on 8 July 2021 .

Creative Commons License 


\title{
Body Matters: Mina Loy and the Art of Intuition
}

\author{
Ellen McWhorter
}

In 1917, the New York Evening Sun famously described Mina Loy as the embodiment of the "Modern Woman." The legend of her artistic originality and personal magnetism is compelling on a number of fronts: attractive, articulate, artistically talented, unconventional, and wildly popular, Loy dipped her hand in numerous careers and media, all the while courting and contouring the most renowned Modernist coteries. Virginia Kouidis explains that, according to the New York Evening Sun, she was described as "a free-verse poet who held 'the intuitional pause exactly the right length of time'; a playwright and actress; a designer of lampshades, magazine covers, and clothing; an authority on Italian Futurism; and a painter" (1). Her circle of acquaintances was no less extensive than her list of creative professions.

2 Modernist scholars have found telling remarks by some of these figures about what it was that made Loy and her work so "new." The most straightforward are summarized by Roger Conover in the introduction to his definitive collection of her work, Lost Lunar Baedecker (1996), in the following way: "In memoir after modernist memoir, she has been granted a forceful personality, cerebral bearing, a perfect complexion, and a sexual body" (xii). More recently, in The Salt Companion to Mina Loy (2010), editors Rachel Potter and Suzanne Hobson identify Loy as "a brilliant literary enigma" (1). But what did the author of the Evening 
Sun article mean by describing Loy as a writer who "held 'the intuitional pause exactly the right length of time'"? What has intuition to do with writing? Why link intuition of all things with the New Woman par excellence?

3 While the author's characterization is unusual, it does not stand alone in its association of Loy with alternative modes of knowing. Gertrude Stein, for instance, having solicited feedback on her then embryonic project The Making of Americans (1925), famously remarked that Loy "was able to understand without the commas. She has always been able to understand" (qtd. in Burke, 130). An important yet understated component of Loy's intuitive understanding as expressed in her poems was, and remains, her "signature elusiveness," iwhich Potter and Hobson claim "is one of her key literary achievements" (6). Yet despite her intuitive understanding, Loy found herself in a cultural and historical moment that privileged the scientific over the intuitive, the denotative over the connotative, and the logical over the ambiguous. As a person and as a poet, Loy challenged this privileging and found consistently inventive ways to express intuitions that had become discredited in then-current scientific and philosophical discourses. She proved to be, in Conover's words, "a binarian's nightmare" (xiii). As Harriet Monroe observed, "Yes, poetry is in this lady whether she writes it or not" (qtd. in Koudis, 19). But whether or not Loy is poetic to the core, her "signature elusiveness" has met with a mixed reception, especially with respect to her most famous (and famously controversial) literary work, Love Songs to Joannes (1917). The initial praise for the poet's personal magnetism has turned, over time, into a criticism of her negative, or at the very least ambivalent, portrayals of love. 4 This criticism has resulted, in part, from a resistance to the modes of knowing that Loy's poem sequence relies on for its power. She sought to express knowledge wrought out of the complicated messiness of lived experience rather than solely cerebral machinations.

${ }_{4}$ In the pages that follow I argue that intuitive knowledge is critical to the representations of love and intimacy in Love Songs. The significance of Loy's representations of intuition-or the desire to "mean" below the radarmanifests in the discursive antagonisms of Love Songs to Joannes. The poem strains under the weight of the conflict between Joannes's cognitive and individualistic world view and the speaker's intuitive and embodied one. This division 
underscores a cultural moment whereby reason and fact came to be aligned with scientific and technological achievement wholly cut off from the messier insights of ordinary human experience. The confluence of scientific and technological discoveries, inventions, and achievements during the period of early modernity opened a space for technology to speak for the body and to tell ordinary people that what they felt was less true than what scientists could see.

5 The new in Loy's poem sequence is found not only in its resistance to increasingly pervasive scientific models of sense making or its high Modernist form, but in its attempt to engage with our fullest human capacities of knowing and saying. For Loy and for the speaker of the poem sequence, knowledge about the world gained and presented intuitively -through lived experience, through embodiment-cannot be straightforwardly articulated, whether in an elaborate costume or an elaborate poem; for certain experiential truths to be shown at all, they must be made to function beyond the privileged ways of knowing and saying that structured the modern world. In Loy's hands, the classic Poundian injunction to "Make it New!" takes on the greatest of ironies; the highly experimental Love Songs pivots around what is most ordinary: our messy experience of embodiment and our attempts to share what we know to be true, rational or not, with others.ii

${ }_{6}$ Historically, intuition has been broadly defined and differently valued. It has been variously seen as a way of knowing that accesses the most abstract "forms" of truth (Plato), a vehicle for spirituality (Thomas Merton), a component of the human psyche akin to the unconscious (Carl Jung), a product of the "right" brain doing its job (Roger Sperry), a byproduct of patriarchal categorization that makes possible l'écriture féminine (Hélène Cixous), iii and a capacity we have evolved to respond to the increasing amount of stimuli in modern societies (Gerd Gigerenzer), among other things. It has also been perceived by its many detractors as an idea fabricated by "New Age" thinkers, anti-rationalists, and occultists. Until recent years, its most consistent features have been its position opposite rationality and, more often than not, its association with non-dominant social groups (e.g., women, children, and people of color).

${ }_{7}$ Few thinkers had as much of an impact on popular models of sense making during the period of modernity 
than Sigmund Freud, and literary scholars Carolyn Burke and Keith Tuma have both documented Loy's familiarity with the work and the man who penned it. With his theory of the unconscious, Freud articulated for the first time the idea that human psychology is comprised of both knowable and largely elusive, though equally significant, components. At a time when science asserted the factuality, stability, and rationality of its "truths," Freud forced those within and beyond the medical field to at least for a moment consider that rational, scientific forms of knowledge and discourse could only capture at most half of the human psyche. Further, he (perhaps unintentionally) challenged the dominant Western association of men with rationality and women with feeling by asserting that human beings in general are guided by both conscious and unconscious forces. This being said, while Freud may have recognized the limitation of a strictly rational perspective on modes of knowing, he also aligned his own work exclusively with scientific inquiry, as epitomized in the following quotation: "The poets and philosophers before me discovered the unconscious; what I discovered was the scientific method by which the unconscious can be studied" (qtd. in Birch, 29). This method, including many of its underlying assumptions about gender and sexuality, leads Freud to some deeply problematic conclusions that have frequently been seen to cast a negative light on his work as a whole, as scholars including Simone de Beauvoir and Luce Irigaray have noted.iv Nonetheless, for the purposes of this essay, Freud's work on the unconscious marks an important early $20^{\text {th }}$-century moment when the existence of alternative forms of knowledge became widely acknowledged as part of the human condition.

${ }_{8}$ For much of the remainder of the first half of the $20^{\text {th }}$ century, little work on intuition or alternative forms of knowledge more broadly occurred outside the discipline of psychology and practice of psychoanalysis, and even less was perceived as scientifically credible. Carl Jung, for example, was first considered Freud's protégé; however, he lost favor with most early to mid $20^{\text {th }}$ century academics when his work veered too sharply toward the study of alternative forms of knowledge. Specifically, Jung positioned intuition next to sensation in what would come to be known as his "personality typology." While Freud's work has been adopted as common knowledge, with many of his ideas having made their way into popular culture in the 
forms of armchair dream analysis, Freudian slips, and the common assumption that the unconscious is a real thing, Jung is best known for his personal relationship to Freud and the "personality test" based on his work that was made popular by Katharine Briggs, Isabel Meyers, and later put online by David Keirsey. The idea of the unconscious may have gained popularity as the century progressed, but the modes of knowing that most directly complicated and defied scientific explanation remained on the epistemological sideline. ${ }^{v}$

9 With Women's Ways of Knowing: The Development of Self, Voice, and Mind (1986), authors Mary Field Belenky et al. reinvigorated the study of intuition by investigating the epistemological perspectives from which late $20^{\text {th }}$-century American women make sense of the world. Unlike Freud's, their work at its very core identifies and queries the pervasive association in Western culture between women and intuition (as opposed to the association between men and rationality) and begins with the acknowledgement that previous studies of ways of knowing have focused solely on male subjects. The authors note:

\footnotetext{
Relatively little attention has been given to modes of learning, knowing, and valuing that may be specific to, or at least common in, women. It is likely that the commonly accepted stereotype of women's thinking as emotional, intuitive, and personalized has contributed to the devaluation of women's minds and contributions, particularly in Western technologically oriented cultures, which value rationalism and objectivity (Sampson 1978). It is generally assumed that intuitive knowledge is more primitive, therefore less valuable, than so-called objective modes of knowing. (6)
}

Through a series of interviews with 135 women performed over the course of five years, the authors identify five positionalities through which women come to knowledge, only the most advanced of which, called Constructed Knowledge, unites "reason and intuition and the expertise of others" while also allowing for women to "jump outside' the frames and systems authorities provide and create their own frame" (133-134). vi Constructed Knowers are the only group noted by the authors that can successfully handle multiplicity, ambiguity, and complexity, which are all characteristics of actual lived experience in the world and terms frequently associated with the period of literary modernity. The authors write: "[Constructed Knowers] want to avoid what they perceive to be a shortcoming in many men-the tendency to compartmentalize thought and feeling, home and work, self and other. In women, there is an impetus to try to deal with life, internal and external, in all its complexity. And they want to develop a voice of their 
own to communicate to others their understanding of life's complexity" (137). According to the authors, intuition plays a key role in not only what we know, but how we articulate our experiences. With their five positionalities, Belenky et al. add important details and scholarly credibility to the articulation of multiple ways of knowing, including the experience of intuition, and at the same time challenge the masculine biases of previous studies. Written decades after Loy's poem sequence, Women's Ways of Knowing brings into articulation a connection between gender roles and ways of knowing that has been largely disregarded in the scholarly study of Love Songs.

${ }_{11}$ In more recent years, numerous scholars including Teresa Brennan, Antonio Damasio, Gerd Gigerenzer, and Malcolm Gladwell have re-approached and to some degree wholly revalued popular conceptions of intuition; the new models of sense making that they present help us most fully engage the facets of Loy's poem sequence that have been historically overlooked. Each takes up the question of how we know what we know when knowledge comes to us not in the form of deliberation or conscious rationalization, but rather out of our very ordinary, immediate lived experiences -the sort which typically require us to process information rapidly and then make split-second decisions in response to stimuli. Gladwell and Gigerenzer, specifically, guide Freud's early $20^{\text {th }}$-century identification of the unconscious into the $21^{\text {st }}$ century and articulate the ways that human knowledge comes not only in the form of rationality and deliberation, but also through intuitions and gut instincts. Neither, however, focuses as explicitly on the entire human body as an organic site for knowing as Damasio does in Descartes' Error: Emotion, Reason, and the Human Brain (1994). Indeed, Damasio, Professor of Neuroscience, Neurology, and Psychology at the University of Southern California, explores the connection between reason and emotion not by simply locating regions in the brain that are responsible for "feelings," but by arguing "that the essence of a feeling may not be an elusive mental quality attached to an object, but rather the direct perception of a specific landscape: that of the body" (xviii). Embodied intuition, he asserts, is "all courtesy of emotion and much past practice" (xiii).

${ }_{12}$ Though he is a neurologist by training, Damasio specifically critiques the version of science instituted in the early 1900s that "gave a resolute cold shoulder to emotion research" (ix). It is worth noting the date that he gives 
here: this is precisely the version of science that Loy's speaker challenges; it is the version that cemented Freud's legacy while minimizing Jung's. Intervening in the Cartesian legacy of dividing mind and body to which the title of his book gestures, Damasio invests the body with knowledge, and examines the brain in the context of full human embodiment (inclusive of emotion). While early $20^{\text {th }}$ century versions of sense making did not include considerations of full, lived human experiences in their constructions of "truth," Damasio and several other contemporary thinkers challenge truth claims that would disembody, distort, and detach humans from the actual conditions of their lives. In Damasio's words, "our most refined thoughts and best actions, our greatest joys and deepest sorrows, use the body as a yardstick" (xx).

${ }_{13}$ In his 2007 book entitled Gut Feelings: The Intelligence of the Unconscious, Gerd Gigerenzer, director at the Max Planck Institute for Human Development, asserts that "the mind adapts [to] and economizes" the constant barrage of stimuli and information presented in the day-to-day experience of living (4). Beginning with the claim that "The laws in the real world are puzzlingly different from those in the logical, idealized world," he illustrates how, given this state of affairs, human minds can thankfully do more than just perform feats of logic; gut instincts and intuitions, he argues, come to us via "rules of thumb," "evolved capacities," and the unconscious. In Gigerenzer's words:

intuition is the steering wheel of life. Intelligence is frequently at work without conscious thought. In fact, the cerebral cortex in which the flame of consciousness resides is packed with unconscious processes, as are the older parts of our brain. It would be erroneous to assume that intelligence is necessarily conscious and deliberate.... We know more than we can tell. (16)

In Loy's early $20^{\text {th }}$-century attempt to articulate the "more than we can tell," we may justifiably sense a body of thought that extends well beyond the Modernist moment and into our own. As the studies of New Materialism and New Formalism have developed in the last two decades, the field of literary studies has seen a marked shift towards a reimagining of the characteristics of human experience generally, and aesthetic experience specifically, that have undergirded definitions of the Humanities in the first place.vii In this spirit, Loy's Lost Lunar Baedecker can and should be seen to act not only as "Twentieth-century poetry's lost guidebook" (xiii), in Conover's words, but also a guidebook to $20^{\text {th }}$ and $21^{\text {st }}$ century ways of knowing more broadly. 


\section{The Universe as Colorless Onion: Scientific Sense- Making}

${ }_{15}$ The late $19^{\text {th }}$ and early $20^{\text {th }}$ centuries brought forth an onslaught of developments that came to define the era as "progressive." From Sturtevant's 1913 turn inward, which brought about the creation of the first chromosomal map, to Goddard's 1916 gaze upward, which followed the ignition of the first liquid fuel rocket, technical knowledge of the world was expanding exponentially in all directions. Building off of developments in machine technology and its attendant scientific apparatuses, medical science in particular asserted itself in a new way in the early $20^{\text {th }}$ century. Because of discoveries that allowed for the manufacture of mass-produced innovations like vaccines, alongside the creation of instruments for seeing and curing the body in new ways (for instance, the X-ray), modern subjects came to see medicine as a "stable" and "factual" field. How, after all, could the machines that supposedly gave unbiased views of the inside of our bodies possibly not reveal facts (and core facts of life, at that)? In this vein, medical science proper developed highly mechanized views of the body which over the course of several decades cemented a way of seeing human beings that defined these "facts" of embodiment according to the characteristics of mechanization, the measurable, and the provable.viii

${ }_{16}$ As Drew Leder explains, science has had a long history of treating humans as animated corpses, as things to be dissected and analyzed rather than understood in their totality. But during the period of American modernity, scientific and technological developments occurred so frequently and were so widely known among the populace that more and more holistic ways of knowing, such as the instincts one has about the health or sickness of their body, became devalued. Moreover, the newly scientific view came to hold sway within the populace at large because of the layperson's desire to be a part of the "progress" that marked America's ascendancy to world power. Intuitions about human dynamics or individuals' experiences of their own bodies, differentially applied to women, minorities, and all combinations therein, came to be devalued within and outside the fields of science because they were not provable, factual, or quantifiable in its mechanized terms. Like cars, bodies were largely viewed as things to be 
brought in for regular servicing instead of complex navigation systems that co-create our experiences of both the scientific and unscientific world.

${ }_{17}$ As medical science during the early $20^{\text {th }}$ century makes bodies into animated corpses, which is to say fleshy bodies comprised of component parts, so does the alignment of science with "factuality," "objectivity," and progress give it powerful control over what are considered to be the characteristics of knowledge more generally. While there were exceptional and highly specialized thinkers such as Einstein or Heisenberg, who explored the relativity of truth claims, the scientifically- and technologically-discovered "facts" that made their way into the mainstream tended to downplay notions of uncertainty in favor of sureness. In the U.S. specifically, certainty of knowledge met with increased government and university funding, which in turn cemented the practical and abstract influence of the "factual" disciplines on American's structures of power. ${ }^{\text {ix }}$

${ }_{18}$ Given this state of affairs, contemporary readers might be surprised by the ease with which Loy's Modernist speaker describes some of life's more complicated components. It is, in fact, quite difficult to read Love Songs without being, at first, surprised by Loy's frank and frequently grotesque descriptions of bodies and bodily processes. At the outset of the first poem, it is clear that this is not a naïve or traditional love song, one replete with poetic promises of forevermore and only the slightest hint

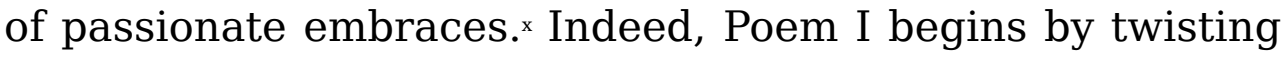
the fairytale love story of Cupid and his amorous arrows into an imagistic, reproductive nightmare narrative of "Pig Cupid"-whom Elizabeth Majerus aptly describes as "Loy's buffoonish hybrid of crude lust and idealized love" (Modern American Poetry) - frolicking among "erotic garbage" (line 4). The imagery is unequivocal: this "garbage" is made up of burrowing sperm-"a weed white star-topped" (line 6) that is "sown in mucous membrane" (line 7). Further, the description also conjures notions of a cupid-turnedabortionist, a trope that the speaker returns to in Poems IV and XVII; his "rooting" (line 4) would likely dislodge any successful fertilization. More to the point, with the revised fairy tale of Pig Cupid snuffling around in sexual waste, and specifically with the phrase "mucous membrane," Loy begins a litany of grotesque biological language that will later come to include "saliva" (Poem I, line 12), a "skin sack" (Poem II, line 1), "spermatozoa" (Poem IX, line 6), the 
"humid carnage" of bodies (Poem XII, line 3), a gooey "procreative truth" (Poem XXIV, line 1) that drips "In pestilent / Tear drops" (lines 3-4), "cymophanous sweat" (Poem XXVIII, line 18), "seismic orgasm" (Poem XXIX, line 29 ), and the "Proto-plasm" from which life evolves (Poem XXXIII, line 3).

${ }_{19}$ Loy's representation of these bodily functions echoes the "facts" attending to sexualized bodies; saliva is, of course, associated with sexual acts, as can be testicles, sweat, and orgasms. Certainly, bodies engaged in sex can become overheated and "humid," and as bodily fluids are conjured and exchanged, it is entirely likely that some may drip. It is important to note, however, that Loy's litany, while explicitly figuring bodies that could be described erotically, especially those involved in sex acts, does not eroticize these particular descriptions given by the speaker, which in turn points readers to the limitations of scientific discourse in the early $20^{\text {th }}$ century. Loy's clinical words and phrases effectively highlight what is missing from purely rational or scientific accounts of human sexual experience: intimacy, beauty, and all of the subtle "unspokens" of sex, such as an intensity of connection so strong that words are not needed to communicate, silent coordination of movements, flooding emotions, or even feelings of sublimity. The most "straightforward" and de-mystified language is presented here, and one cannot help but feel as though something is deeply problematic about-or missing from-Loy's descriptions.

${ }_{20}$ Some scholars, including Virginia Kouidis, have interpreted Loy's deployment of scientific language as proof of the poems' "disillusioned and cynical analysis of religious and romantic love" (14). Even Monroe, Loy's contemporary, asked "how could one so beautiful be so unsparing in her revelation of the ugliness in herself, and so sardonic about love?" (qtd. in Conover, xv). In these readings of the poems, the speaker's exploitation of the dominant discourse for sense-making is taken to register a pessimism about the possibility for love and sex to coexist in a modern day relationship, rather than a critique of the discourses themselves. (Monroe's attribution of the "ugliness" to Loy's person instead of to the biological language itself serves as an extreme example.) To read Love Songs as pessimistic in its representation of love, however, downplays the significance of what lies beyond the dominant discourses (i.e., intuitive understanding), which is precisely where the 
poem locates value and hope, including the hope for a more thriving intimate relationship.

${ }_{21}$ The ambivalent representations of embodiment and sex in Loy's work have been noted before by critics including Rachel Blau DuPlessis, Paul Peppis, and Eric Murphy Selinger. Sexuality is often either straightforwardly addressed (in the form of naming) in the poems or graphically metaphorized, but with little room for subtlety. In fact, the poems' most infamous description likens sex not to a tender waltz or romp in a flower field, as the reader of conventional love poetry might expect, but rather to a badminton game: "Shuttle-cock and battle-door / A little pink love / and feathers are strewn" (Poem X, lines 1-3). The activity itself is playful-it is a game, after all-but the imagery emphasizes competition and roughness. Loy's change of the standard "battledore," the racket used in games like badminton, into two words: "battle-door" functions as but one way to emphasizethe competitive aspect of the game. Both players end up disheveled when "cock" and "a little pink love" are put into play. Moreover, Loy's witty but explicit use of the word "cock" here continues the graphic description of male genitalia begun in Poem II. Though this poem contains the only obvious likening of sex with sport, the idea of sexual competition appears in others. Loy's speaker is at times critical of her lover's sexual prowess, and her words sometimes resemble the "trash talking" that accompanies some sporting events. For instance, when describing the different sexual trajectories for the speaker and Joannes, she begins by reducing him to a mere component part-his testicles-and then proceeds to liken him sexually to "a clock-work mechanism / Running down against time" (Poem II, lines 7-8). ${ }^{\text {ii }}$ In her objectification of him, she informs the reader that the buzzer has sounded and the match has ended unceremoniously.

${ }_{22}$ In Modernist Writings and Religio-Scientific Discourse: H.D., Loy, and Toomer (2010), Lara Vetter ascribes to various poets what Susan McCabb had previously called a "crisis of embodiment" in the early $20^{\text {th }}$ century. For Vetter, poems by Loy and others reveal "anxiety about the body's integrity" (2) in the face of a scientific world that sought to penetrate it in order to understand its complexities. Love Songs is fraught with the jargon of biology precisely in order to voice an objection to what science has made of the bodies with which we experience all of the poems' other 
thrusts, such as love, sex, and communication. To this degree, Andrew Michael Roberts is persuasive when he claims that "Loy resisted a masculinist repression or denial of the body" (139), but we should add that her uncomfortable deployment of specifically biologicallynamed bodies also has the effect of challenging discourses that repressed certain understandings and experiences of bodies as well. Biologized and mechanized bodies speak in the poem sequence, but not straightforwardly. Loy's speaker challenges what Vetter characterizes as "an acute collective anxiety about control over one's body" (17) by fighting from beginning to end to give bodies the power to communicate and know things beyond "fact." xii She not only laments what she wants to share but cannot share with Joannes-something inclusive of unspoken emotional communication, something more akin to the full human experience-but she also fights for its legitimacy against the various social forces that downplay its importance. While Joannes lives the life of the mind, the speaker lives the life of real, human, lived experience, complete with things that do not quite compute into the models of knowing, saying, and loving with which Joannes is familiar.

${ }_{23}$ At this point, it is worth briefly noting how Joannes is represented outside of the realm of sexuality. The characteristics with which he is aligned, and his modes of operating in the world tell us much about the oft-noted tensions between the lovers and even more about the tensions between the speaker's life and "the rule book." Joannes represents for the speaker of Love Songs a power and scope that is more mechanical than human, as sizable as biology and as solid as science. He both is defined by the characteristics of and embraces the god-like pursuits of the mind, and in no small way Loy's speaker feels both the limitations and attractiveness of this way of being. Like the biological components to which he is repeatedly reduced, not the least of which is the aforementioned "skin sack" of Poem II, Joannes lives in the land of reductive sensemaking. Beyond incompatible sexual trajectories, and even beyond tensely differing models of romantic love, Loy's speaker objects to and pushes against the very ways of existing in the world that Joannes both wholly subscribes to and represents. These include his mechanistic form of sexuality, but also extends well beyond it.

24As the epistolary Poem XI figures him, Joannes is a dissector rather than a gentle observer of the world: 


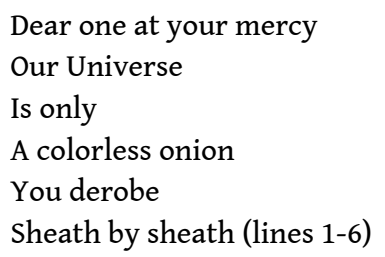

The world, for Joannes, is a thing to be disassembled for the sake of understanding, just as the "animated corpses" noted by Leder are ripe for dissection. Like a scientist, Joannes peels away facts and layers of truth as he comes to understand them, always searching for what can be revealed by the next level of dissection. Naturally demarcated from the others, the sheaths represent pieces of a whole, units with clear borders, ideas clearly differentiated from one another. In the process of disassembly, the world/onion in its organic wholeness is destroyed; any interplay between units, or any explanation beyond the sum of its parts is reduced to nothing but "a disheartening odor" (line 8) left on his "nervy hands" (line 9). "Our Universe," the speaker implies, loses its vibrancy under the microscopic eye of thinker/automaton Joannes, and, as readers of Love Songs will recognize, this speaker has a passion for the colorful. Indeed, the poem sequence begins with the speaker moving into her "Coloured glass" lantern to speak (Poem I, line 18), capitalized "Love" is described in Poem IX as "A Cosmos / Of coloured voices / And laughing honey" (lines 3-5), and Poem XXVIII is all about the pain of "whiteness" in the absence of Joannes's presence (line 7).

26Joannes navigates the world of cognition, which is to say the world of what can be very clearly rationalized, proven, and compartmentalized, and-like the method of operation by which he is characterized-he maintains a certain cultural purchase and power to the speaker, even if her longings for deeper communion with him go repeatedly unfulfilled. Sexually, as we have seen above, Joannes is mechanical and, therefore, lackluster. Even his sexual experiences are broken into units, seconds to be precise; his "clockwork mechanism" runs down before the speaker is fulfilled, suggesting that the difference between his time/ sexuality and hers has to do with fragmented-ness and pacing. In the bedroom and, implicitly, outside of it, the regularity and predictability of Joannes's world and experiences conflict with the speaker's. Unable or unwilling to make room for experiences that deny what I am characterizing as his scientific way of experiencing the 
world, he functions as a powerful representative of "progress" and, simultaneously, a dismal representation of what it means to experience ordinary embodiment and a more profound intimate love.

${ }_{27}$ Joannes's model for reductive sense-making informs his relationships with more than just the speaker; in fact, it is precisely what secures his power in the world at large. Time and again in Love Songs, Joannes speaks the conceptual language of his time. His god-like pursuits of objectivity and fact, and his complete dismissal of the speaker's intuitive knowledge and emotional insights, match the models for sense-making popularized and privileged at the beginning of the $20^{\text {th }}$ century. Decades after Loy's formulation, the Constructed Knowers studied by Belenky et al. would note a similar break between a male "tendency to compartmentalize" and their own tendency to want to communicate about life's complexities. In the poem sequence, Joannes sacrifices the messy, ambiguous, fullness of human experience for that which can be clearly formulated; when in her idealistic moments the speaker longs for a deep, one might even say "borderless," connection with her beloved, Joannes basks in the individualism that keeps him "apart / Inviolate in an utter crystallization" (Poem XII, lines 8-9). Whereas he seeks and finds truths that are "everlasting" and "apparent" (Poem XIV, line 2), the speaker finds the greatest significance in the "passing" and "imperceptible." Put in the terms of this essay, where Joannes willfully embraces the scientific and the characteristics associated with it, the speaker locates important truths in "embodied intuition," to borrow Damasio's phrasing.

${ }_{28}$ In various poems, the speaker laments Joannes's distance from her; at times she pokes fun at him while at others she appears heartbroken. However, both forms of address make abundantly clear the fact that Joannes's preference for separation over togetherness is a major cause of tension in their relationship. Separation is both literal and conceptual for Joannes; his mind works to separate onion sheaths while he more literally separates himself from his lover. Poem XIII reads:

oh that's right

Keep away from me Please give me a push

Don't let me understand you Don't realise me

Or we might tumble together

Depersonalized

Identical 
Into the terrific Nirvana (lines 23-29)

29 Here in the poem sequence's lone instance of direct address, the speaker begins by launching an almost childish attack on Joannes's physical separatedness; as the outburst continues, it becomes clearer that the deeper problem is his ability to create mental walls between himself and her. By the end of the poem, Joannes's self-imposed distance takes on the greatest of proportions, standing in as the cause of their fall from a state of eternal, conjoined transcendence. At the end of the sequence, the speaker imagines Joannes as a galaxy away from her, as she is "burnt quite white / In the climacteric / Withdrawal of [his] sun" (Poem XXVIII, lines 10-12).

${ }_{30}$ Lest this hyperbolization of Joannes's power seem almost hysterical, it is worth noting that Joannes's way of being in the world is often characterized in the poem by his god-like pursuits of the mind. (In truth, one gets the sense that the speaker is not the only person who thinks of Joannes as god-like.) And like a god, he creates the world as he moves through it, leaving the speaker behind to puzzle her way through it and back to him. Poem V ends with the speaker at a literal crossroads, "undecided" about "which way back" (line 4), implicitly, to home and her beloved. She muses: "And I don't know which turning to take / Since you got home to yourself-first" (lines 14-15). Here the speaker puts herself and Joannes in a very common domestic scene -the walking home after an evening out together-and in it Joannes paves the way, taking himself home first and leaving her to follow behind. Later, Joannes's agency also takes on larger proportions, as his walking creates rather than follows sidewalks. Again, the speaker lags behind: "My pair of feet / Smack the flag-stones / That are something left over from your walking" (Poem VII, lines 1-3). More than just an indication of the couple's power dynamic, these poems suggest that there is for the speaker an incredible power to Joannes's way of moving in the world, and it is this power that the speaker alternately resists and submits to.

${ }_{31}$ Sadly for the speaker, the same beloved whose hair marks "A God's doormat / On the threshold of [his] mind" transforms the speaker into "the jealous store-house of the candle-ends / That lit [his] adolescent learning" (Poem VIII, lines 1-2). Like the universe reduced to a "colorless onion," the speaker moves from human to "store-house" under Joannes's supremely rational and measured way of knowing and experiencing the world. As he matures, the rest of 
Poem VIII makes clear, Joannes finds "other lights" (line 4) less in sexual intimacy with the speaker and more in his own mind, "Behind God's eyes." For the many reasons discussed above, the speaker's feelings for Joannes, while never ceasing to be intense, are deeply ambivalent. She stands in awe of his power in the world and of his mental prowess. It could even be said that part of her attraction lies in the pursuit of him. At the same time, the speaker moves repeatedly into a creative world where she constructs her ideal mate. The speaker's longing for an unspoken and intuitive kind of love - the one that she measures Joannes against-saturates her musings with, at times, confusion and, at others, profound pain. For all of the moments rendered in the poems during which the speaker submits to in one way or another, or even insists upon, Joannes's godlike stature, there are also moments of harsh critique. For every self-conscious moment in which the speaker sets Joannes "apart / Inviolate in an utter crystallization" (Poem XII, lines 8-9), there is a moment of backlash during which he is not just humanized but dehumanized, such as being reduced to the "skin sack" of which he is in possession.

${ }_{32}$ Scholars of Loy's work have already noted that the speaker alternates between lamentation for the love that she and Joannes could have had, or perhaps even did in moments, and her scathing indictment of it. This play between seemingly irreconcilable positions is but one of many in the poem sequence. DuPlessis, Majerus, Peppis, Peter Quartermain, and others have in recent years drawn critical attention to the speaker's simultaneous love for and anger at Joannes, her pressing visions of an ideal love and her attachment to her real lackluster one, her explicit references to bodies and bodily processes alongside a critique of scientific reductivity, and so on. DuPlessis, for example, in "'Seismic Orgasm': Sexual Intercourse and Narrative Meaning in Mina Loy," approaches the conflicting messages about feminism in Loy's work by showing that the straightforward representations of sex acts are, on the one hand "clear statements of a New Woman position" (51). On the other hand, she shows, Loy also rejects contemporary feminist platforms, because for her "political reforms calling for 'equality,' among them female suffrage, equal education, and professional opportunity" miss the mark (51). 
${ }_{33}$ Accordingly, Poem XV contains both deification and its deconstruction. It begins by differentiating Joannes from other men: whereas they are mere mortals, he is something altogether grander.

Seldom Trying for Love

Fantasy dealt them out as gods

Two or three men looked only human

But you alone

Superhuman apparently (lines 1-5)

For reasons other than love, "Fantasy," under whose name the couplings begin, attempts to dress ordinary men up as gods, but the speaker sees immediately that only Joannes is truly god-like. Or is he? The poem goes on to explain that being perceived as "Superhuman" requires a beloved to paradoxically see and love the most ordinary of human features. Loy continues: "I had to be caught in the weak eddy / Of your driveling humanity / To love you most" (lines 6-8). For the speaker here, this is the "reality" which goes beyond the "Fantasy." By extension, love in the poem's construction requires a revaluation of what is most "real" in the first place: the dominant discourse, which privileges a mind like Joannes's, or the experiential, which relies on embodied intuitions and instincts that the dominant discourse discredits.

\section{2. "With human throats / and Wisdom's eyes": Loy's Rendering of the "Inconceivable concept"}

${ }_{35}$ The $20^{\text {th }}$ century ushered in a new degree of correlation between scientific rationalism and "truth" more generally, as evidenced by the fact that even Freud, the father of psychoanalysis, insisted on positioning his work not within the study of alternative forms of knowing, but rather within the field of strictly rational science. It is this same correlation that inspired fellow Modernist William Carlos Williams, himself a medical doctor, to assert in Spring and All (1923) that "The inundation of intelligence by masses of complicated fact is not knowledge" (225) and it is this correlation against which Loy's poem sequence presents its feminist revision. Like Freud, her contemporary, Loy is deeply invested in acknowledging the reality and value of alternative ways of knowing; unlike Freud, she deploys the masculine discourse of science only while simultaneously pointing out its limitations. More in line with Damasio, Loy turns to lived, embodied human experience in order to 
articulate the pure language of intuition; this pure language acknowledges the fact that, to use Gigerenzer's words, "we know more than we can tell."

${ }_{36}$ Loy has historically been lumped together with Stein and H.D. under the category of "experimental" poets, even if she has not been as easily adopted into the literary canon. But, in the case of Love Songs, to what extent is experimental any different from experiential? To speak of things that are experienced and known, but which are not experienced and known through the credible channels (i.e., rationality, straightforwardly linguistic articulation) requires a poet to reinvent the way that discourse "means" in the first place. Intuition, described in Poem XXVII as an "inconceivable concept" (line 2), requires a different form of articulation, a "new" form of expression, and these can occur not only in what is said, but in what is not said or what triggers a pause. Consequently, in the poem the speaker's knowledge comes to us indirectly, unlike the truths that Joannes seeks, which can be directly formulated and stated. Her knowledge is more intuitive than scientific, more underground than easily accessible, and more embodied than mechanical or scientific. In a world and time when science and industry came to define both what was knowable, privileged, and above all straightforwardly sayable, a speaker attempting to share knowledge wrought from full human experience would encounter difficulties indeed. The poem thus strains not under the weight of pessimism, but under the weight of what philosopher William James calls the "fulness [sic] of the truth," which defies the classification and rationality that straightforward language relies on (232). Interpreting Loy's poem sequence is not unlike articulating this "fulness."

${ }_{37}$ One way that Love Songs approaches the unsayable is by pushing the sayable to its outer limits. Through the figure of Joannes, the speaker anthropomorphizes scientific discourse and represents the conceptual characteristics privileged during the early $20^{\text {th }}$ century: Joannes is objective, mechanical, and supremely rational. For these and other reasons, he wields power. He also breaks the speaker's heart, and acts as the catalyst for her passionate rendering of the "real matter" of life. Loy's use of scientific and biological language takes on the ambivalence that the speaker feels for Joannes; while in the popular American consciousness this language is characterized by its affiliation with the objective, mechanical, and rational, it 
also takes on the characteristics of inadequacy and deficiency through its juxtaposition with Joannes. In the end, this language is powerful but disappointing insofar as it does not and cannot address much of the real matter of experience that the speaker wants to communicate, particularly the experience of intimate love.

${ }_{38}$ In Poem XIII, the speaker unequivocally declares that she would like to use language to reveal an important truth but cannot. Loy writes: "Come to me There is something / I have got to tell you and I can't tell / Something taking shape / Something that has a new name" (lines 1-4). While other poems in the sequence focus on the possibilities of interpersonal communication beyond words, here the speaker focuses on an aborted attempt to share a bit of wisdom through language. First drawing her listener physically closer to her, which gives the impression of a secret being whispered, she reveals the wish that language could be harnessed for her purposes. She desires complete disclosure, the ability to share her "new" "something." The gesture of pulling the reader close to the speaker suggests more than just the potentially subversive nature of the "something"; it provides for the possibility that physical presence subtends the act of speech. As readers, we are asked to, in the words of Damasio: "use the whole body as a yardstick." This something in the poem would have a "new name," which marks its present status as part of the unsayable. Considered alongside the other poems, we can surmise that the speaker wants language to help her achieve a more complete expressive symbiosis of life experiences and understanding between herself and her beloved, but she finds that this cannot be conveyed through words; even if she intuits the potency of the embryonic "something," she simply "can't tell" anything more about it. To a significant degree, words are Joannes's medium, a medium of classification and rationality. The speaker, however, draws her listener physically closer, suggesting that in their shared proximity, a very different way of communicating becomes possible.

${ }_{39}$ In her Feminist Manifesto (1914), Loy famously asserts that "there is nothingimpureinsex" (156; original underlining), thus making a statement that parts of Love Songs appear to challenge. Yet in Poem XIII and elsewhere, the speaker of Love Songs reveals a profound desire to inextricably fuse embodiment and language. While the body and sex acts as discussed in the previous section of this 
essay are made less beautiful by biological language, the body as it is explored here serves as the primary site for speaking beyond dominant discourse. Notably, these poems invoke physicality in a very different way. Writing in 1994, Damasio argues: "The organism constituted by the brainbody partnership interacts with the environment as an ensemble, the interaction being of neither the body not the brain alone" (89). In Love Songs, Loy's rendering of alternative ways of understanding language, sex, and love perhaps serve as the most convincing proof of what the world loses under Joannes's gaze. By understanding humans as an "ensemble" of brain and body, her speaker stays attuned to-in Damasio's words-"what we call intuition, the mysterious mechanism by which we arrive at the solution of a problem without reasoning toward it" (188). In the poem sequence, the human experience of "intelligence at work without conscious thought," to borrow Gigerenzer's phrasing, rings significantly more vibrant and true than a strictly rationalist characterization of knowing that favors dissection and compartmentalization.

${ }_{40}$ The multiple poems beginning with the phrase "We might have" tell us much about the speaker's dreams and, moreover, the contrasting reality of her life with Joannes. Where his ways of seeing the world drain it into "A colorless onion," the speaker imagines: "We might have given birth to a butterfly / With the daily news / Printed in blood on its wings" (Poem III, lines 6-8). Equally about the joint creativity that becomes possible with a good romantic match, this poem attests to the colorful world-in the form of a butterfly-that represents successful communication for the speaker. In an ideal world, she and Joannes could not only imbue life with color, but they could make news together. With their ideal union, it would become possible to use language to create the "new dimension" (Poem XIII, line 5), "new use" (line 6), and "new illusion" (line 7). As well, this birth scene is wholly embodied, as is the news itself. Unlike the colorless onion that will be peeled by Joannes to the point at which it becomes nothing, the butterfly is a living being that has color and language running through its wings, the wings that will someday allow it to ascend to the sort of "high" knowledge that Joannes seeks. It is not, thus, through dissection, but through embodiment and wordless wisdom that the greatest truths can be found and, ideally, shared. Through its birth, Loy writes, the butterfly becomes godlike: "Where 
two are three are welded together / They shall become god" (Poem XIII, lines 20-21).

${ }_{41}$ This sentiment is reinforced in the subsequent "We might have" poem, which also figures bodies as important components in articulating the experiential insights that language fails to express. Poem XVI contains one of the poem's most romantic scenes, one heaving with lovely albeit bizarre imagery, for instance going "apple stealing under the sea" (line 3) and tender playfulness in the form of "Hide and seek in love and cob-webs" (line 5). These dream activities conclude with, first, a long conversation, presumably of the sort undertaken by passionate new lovers whose desire to know everything about each other is insatiable. Then crucially, in the speaker's rendering, the words at some point cease, the talking having been so intense that "there were no more tongues / To talk with" (lines 7-8). The usefulness of language simply petering out, the couple would "never have known any better" (line 9). So wholly preoccupied with one another, the communication is complete. And this, I submit, is the ideal for which the speaker strives but which Loy realizes is not easily-if ever -achieved.

${ }_{42}$ In several of the more surreal poems in the sequence, the speaker creates scenarios that, like the dreams they seem to represent, suggest the reemergence of themes already established in the poem but with less explicit portrayal of the anger, lamentation, or intentional critique for which the poem is known. They are represented creatively rather than logically, and require readers to use their imaginations more than their textbooks. They also give us access into the dream-space of the speaker, where language and other forms of interpersonal communication can take on whatever dimensions she wishes. Poem IV, for instance, describes a frieze depicting an "unimaginable family" of "Bird-like abortions / With human throats / And Wisdom's eyes" (lines 3-6). Initially frightening, this imagery becomes tempered as the speaker continues to describe a scene of maternal sweetness. A mix of the animal and the human, and by extension instinct and cognition, "One bore a baby / In a padded porte-enfant / Tied with a sarsenet ribbon" (lines 9-11). As the third stanza makes clear, this scene is greatly appealing to the speaker not just for its unconventional domesticity but because of the secrets that this odd mix points to. Both animal and human, these beings possess for the speaker an enviable wisdom. 
By the end of the poem, the speaker knows two things: this unimaginable family has insights that she does not, and in order to learn them, she cannot use language. Were it not "for the abominable shadows" of their world (line 13), she would hope "To teach them to tell me their secrets / Before [she] guessed / -Sweeping the brood clean out" (lines 16-18). There is something in the pinning down of their wisdom, in the attempt to linguistically formulate the entirety of what is experienced, that would result not only in failure to learn their secrets but also in the untimely demise of the whole "brood." To use Joannes's methods of dissection on the imaginary world in order to understand it is to ensure that the insights will be lost forever. Like the "Constructed Knowers" described by Belenky et al., the speaker would need to "'jump outside' the frames and systems authorities provide" in order to truly understand.

${ }_{43}$ Finally, the passionate sex act itself eludes language. Hardly reminiscent of the mechanical acts performed by the bodies described in the language of science and biology that appear in other parts of the poem, wordless sex in the poem sequence is painted with pleasure and eroticism. Loy writes:

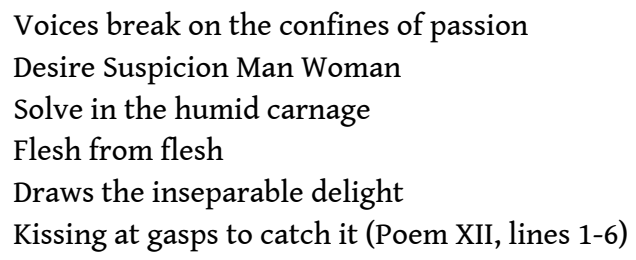

Alternately "voices," which signify individualization, "desire [and] suspicion," and "man [and] woman"-the latter four all clean linguistic distinctions if not oppositions-find a solution in the erotic exchange. According to the list, the first implicit problem to be "solve[d]" is spoken language. And in the sexual exchange, there can be a different kind of communication, a bodily communication that, because it is wordless, facilitates an ephemeral "delight," both in the speaker's representation of the exchange and in the sex itself. The "Voices break on the confines of passion," because the mouths are otherwise engaged in the pursuit of pleasure, "Kissing at gasps to catch it."

${ }_{45}$ At first, this optimistic reading of the speaker's feelings about love and sex might seem contrary to the main thrust of the poem, which can be read for its negative or ambivalent portrayals of love. While it is true that so much of Love Songs vibrates with, in the words of Poem XXIII, "the pure white / wickedness of pain" (lines 8-9), it also 
constantly swings back to lovely and hopeful representations of sex, communication, and embodied knowledge. Further, the representations of pain and hope portray more than just the contrasting emotions that accompany a dissolving relationship; they speak to the cultural conditions of Western modernity. They trace the oscillating perceptions of someone who has had sundry experiences shaped by multiple ways of knowing, and wants to speak of them but finds that they cannot easily put into play a language that works beyond the ubiquitous conceptual categories that position rationality against all other forms of sense making.

${ }_{46}$ Quartermain quotes Loy as saying: "I have no idea what English is, but I am intensely aiming at pure language" (77). As an ideal, pure language would be able to accesses both the said and the unsaid, the intelligence at work with and without rational thought; as such, it would be inclusive of the experiential and represented in poems like Love Songs by embodied intuition, or that which shows Gigerenzer's "more than we can tell." Loy's exploration and attempted rendering of this pure language reveals nothing less than the result of an extraordinary insight into the conceptual models for sense-making that structured the Western modernist world. As a high modernist poem, Love Songs "makes it new" by turning to what is most ordinary: our complicated experience of embodiment and our attempt to share what we know with others. Love Songs represents Loy's deep familiarity with the popular version of science, specifically its versions of rationality, embodiment, and language in the $20^{\text {th }}$ century, as well as a finely-tuned intuition about what is being denied by them. In Descartes' Error, Damasio quotes Jonas Salk, developer of the polio vaccine, as saying "that creativity rests on 'a merging of intuition and reason'” (189). In its creative representation and deployment of the two, Love Songs is in many ways ahead of its time. 


\section{BIBLIOGRAPHY}

“Battledore." The Oxford English Dictionary Online. Oxford English Dictionary, 2008. 21 July 2008. 21 May 2009. Web.

Birch, Charles. Feelings. Sydney: U of New South Wales P, 1995. Print.

Brennan, Teresa. The Transmission of Affect. NY: Cornell UP, 2004. Print.

Burke, Carolyn. Becoming Modern: The Life of Mina Loy. Berkeley, CA: U of California Press, 1997.

Print.

Conover, Roger L. Introduction. The Lost Lunar Baedeker. By Mina Loy. NY: Noonday, 1996. xi-xx. Print.

Damasio, Antonio. Descartes' Error: Emotion, Reason, and the Human Brain. New York: Penguin, 1994. Print.

Duplessis, Rachel Blau. “'Seismic Orgasm': Sexual Intercourse and Narrative Meaning in Mina Loy." Mina Loy: Woman and Poet. Ed. Maeera Schreiber and Keith Tuma. Orono: National Poetry Foundation, 1998. 45-74. Print.

Gaedtke, Andrew. “From Transmissions of Madness to Machines of Writing: Mina Loy's Insel as Clinical Fantasy." Journal of Modern Literature 32.1 (2009): 143-162. Print.

Galvin, Mary E. Queer Poetics: Five Modernist Women Writers. Westport: Praeger, 1999. Print. Gigerenzer, Gerd. Gut Feelings: The Intelligence of the Unconscious. New York: Penguin, 2007. Print. Gladwell, Malcolm. Blink: The Power of Thinking Without Thinking. Back Bay, 2005. Print.

James, William. Essays in Pragmatism. Ed. Alburey Castell. New York: Hafner, 1948. Print.

Kouidis, Virginia. Mina Loy: American Modernist Poet. Baton Rouge, LA: Louisiana State University Press, 1980. Print.

Leder, Drew. Body and Flesh: A Philosophical Reader. Ed. Donn Welton. Malden: Blackwell, 1998. Print.

Loy, Mina. The Lost Lunar Baedeker. Ed. Roger Conover. NY: Noonday, 1996. Print.

Majerus, Elizabeth. “'A Cosmos of Coloured Voices': Connection and Critique in Mina Loy's Hybrid Poetics.” Modern American Poetry. 2000. 1 June 2014. Web.

Peppis, Paul. “Rewriting Sex: Mina Loy, Marie Stopes, and Sexology.” Modernism/Modernity 9.4 (2002): 561-579. Print.

Potter, Rachel, and Suzanne Hobson. Introduction. The Salt Companion to Mina Loy. Ed. Rachel Potter and Suzanne Hobson. London: Salt Publishing, 2010. 1-11. Print.

Quartermain, Peter. “'The Tattle of Tongueplay': Mina Loy's Love Songs.” Mina Loy: Woman and Poet. Ed. Maeera Schreiber and Keith Tuma. Orono: National Poetry Foundation, 1998. 75-85. Print.

Roberts, Andrew Michael. “'How to be Happy in Paris': Mina Loy and the Transvaluation of the Body." The Cambridge Quarterly 27.2 (1998): 129-147. Print.

Schreiber, Maeera, and Keith Tuma. "Introduction." Mina Loy: Woman and Poet. Orono, ME: The National Poetry Foundation, 1998. 11-16. Print. 
Simpson, Megan. Poetic Epistemologies: Gender and Knowing in Women's Language-Oriented Writing. New York, SUNY, 2000. Print.

Tuma, Keith. "English as a 'Second' Language: Mina Loy's Anglo-Mongrels and the Rose." Mina Loy: Woman and Poet. Ed. Maeera Schreiber and Keith Tuma. Orono: National Poetry Foundation, 1998. 181-204. Print.

Williams, William Carlos. The Collected Poems of William Carlos Williams, Volume 1: 1909-1939. Ed. A. Walton Litz and Christopher MacGowan. New York: New Directions, 1991. Print.

Vetter, Lara. Modernist Writings and Religio-Scientific Discourse: H.D., Loy, and Toomer. New York: Palgrave MacMillan, 2010. Print.

\section{NOTES}

i. Maeera Schreiber and Keith Tuma refer to "the mysteries of Mina Loy" and "Loy's signature elusiveness" in their 1998 collection of critical essays entitled Mina Loy: Woman and Poet (10-11).

ii. Roger Conover notes that Loy's career "was marked by so many seeming contradictions, counter-allegiances, and inconsistencies that she was often considered unbalanced" (xiii). In its portrayal of our messy lived experiences, Love Songs thus serves as further proof of Loy's desire to represent and occupy the space "in between" clearly defined categories and binary oppositions.

iii. Cixous is but one of the post-Freudian, French feminist scholars who links alternative ways of knowing, writing, and women's embodiment. For a recent discussion of French feminist deployments of non-patriarchal language, especially as it relates to poetic discourse, see Megan Simpson's Poetic Epistemologies: Gender and Knowing in Women's Language-Oriented Writing (2000).

iv. Specifically, Freud's articulation of the Electra complex, his conception of penis envy, and his understanding of lesbian sexuality have been frequently critiqued.

v. Aside from Jung's writings, there is a vast literature in the late nineteenth and early twentieth century that explores irrationality, instinct, and intuition in human psychology, from authors such as William James and John Dewey in the United States to continental thinkers such as Edmund Husserl and Maurice Merleau-Ponty. While the rich possibilities offered by these thinkers are noteworthy, Freud remains the most significant cultural touchstone for representations of alternative ways of knowing.

vi. The authors note that intuition alone, which plays the greatest role in the third of their positionalities, called Subjective Knowing, is not always already a "good" thing because Subjective Knowers all too often imagine it as infallible rather than as one successful way of knowing that co-exists with others.

vii. For a more detailed discussion of the role that intuition plays in the Humanities, see Teresa Brennan's The Transmission of Affect (2004).

viii. It should be noted that I am not suggesting that the conceptual division between mind and body is unique to the late $19^{\text {th }} /$ early $20^{\text {th }}$ century. Such a division can surely be seen in texts that go back as far as Plato and Aristotle, and perhaps even farther. Rather, I am positioning the division within a specific cultural and historical moment where the advancements of science and technology intersected with previously unimaginable amounts of funding and popular support.

ix. This increase in University funding of the scientific disciplines is, in part, what inspired T.S. Eliot and others to formulate the tenets of New Criticism in the manner that they did, by simultaneously pointing out the limitations of a purely rational view of human experience while deploying its certainty of knowledge and, at times, its language. 
x. T.S. Eliot similarly juxtaposes representations of love and the scientific gaze in "The Love Song of J. Alfred Prufrock" (1915), though in this case the cumulative effect points more directly to the psychology of the speaker than to the cultural conditions of the Modernist period.

xi. In an essay on Loy's rarely examined novel Insel, entitled "From Transmissions of Madness to Machines of Writing: Mina Loy's Insel as Clinical Fantasy," Andrew Gaedtke observes that the image of something akin to a human "clockwork mechanism" makes a second appearance in Loy's body of work. One of the novel's two main characters, Mrs. Jones, likens Insel to a broken machine, in Gaedtke's words "locating him somewhere between human and machine, but a machine that seems to be in an entropic state of decay and dissolution. He quotes 'A wound up automaton running down, Insel ceased among the clatter of our amusement"” (31).

xii. I do not mean to suggest that Loy's representations of intuition and other alternative forms of knowledge sit neatly opposed to the forms of knowledge privileged by the sciences. Rather, Loy portrays the multiple ways of knowing that come together in our actual navigation of the world, which include both cerebral and embodied components.

xiii. For differing analyses on the significance of color in the poem sequence, see Kouidis, Galvin, and Majerus.

\section{ABSTRACTS}

Intuitive knowledge, which is both mysterious and elusive when set against more dominant models of sense-making in the early $20^{\text {th }}$ century, is critical to the representations of love and intimacy in Mina Loy's famously controversial Love Songs to Joannes. The significance of Loy's representations of intuition-or the desire to "mean" below the radar-manifests in the discursive antagonisms for which the poem is best known. As Love Songs strains under the weight of two conflicting world views, we come to see that Joannes's cognitive and individualistic one stands in contrast with the speaker's intuitive and embodied one. The division between scientific and intuitive modes of knowing occurs within a cultural moment whereby reason and fact came to be aligned with scientific and technological achievement, while being wholly cut off from ordinary human experience and its messier insights. For the speaker of the poem sequence, knowledge about the world gained and presented intuitively, through lived experience and through embodiment, cannot be straightforwardly articulated; for certain experiential truths to be shown at all, they must be made to function beyond the privileged ways of knowing and saying that structured the modern world.

\section{INDEX}

Keywords: embodiment, intuition, Love Songs to Joannes, Mina Loy, modernism

\section{AUTHOR}

\section{ELLEN MCWHORTER}

Merrimack College 